\title{
Limitations to Freedom of Religion or Belief in Georgia: Legislation and State Policy
}

\author{
Ekaterine Chitanava and Mariam Gavtadze* \\ Tolerance and Diversity Institute (TDI) \\ mgavtadze@gmail.com
}

\begin{abstract}
This article demonstrates legal and non-legal limitations of freedom of religion or belief (FoRB) in Georgia, characterized by an absence of relevant case law of common courts about restrictions to FoRB with legitimate aims. Instead, the State is using various instruments for interference, such as administrative barriers and artificial obstacles for religious communities. In certain occasions, its policy and practice do not comply with the constitutional principles and international human rights commitments of the country. The State's preferential treatment of the dominant and influential religious institution, the Georgian Orthodox Church, ostracises other religious communities. This is further aggravated by the attempts of securitising and weaponising FoRB.
\end{abstract}

\section{Keywords}

Georgia - freedom of religion or belief - limitation clauses - national security discrimination - religious minorities

\section{$1 \quad$ Introduction}

The status of freedom of religion or belief and the issue of state-religion relations has been the subject of various discussions and criticism, evolving and shaping in light of political developments in Georgia. In order to explore the

\footnotetext{
* The authors have contributed equally to this article.
} 
limits of the right to freedom of religion or belief (FoRB) in Georgia, it is important to look at the policy and practice of the State and its relation to religious communities in the light of the post-Soviet context.

The recent history of Georgia after gaining political independence in 1990, can be construed according to different forms of nationalism and political transitions. After the collapse of the Soviet Union, the first tenure of the government was characterised by ethnic nationalism. Later State politics were shifted to a system of elite-mediated liberalism (1992-2003). During these years, the Georgian Orthodox Church (GOC) acquired legal and ideological recognition. In 2002, the Constitutional Agreement was signed between the State and the GOC granting special status and privileges to the Church. Since the state institutions were utterly weak, government authorities used the GOC for gaining political legitimacy. In return, the Church also started receiving material and legislative benefits from the state.

The period since 2003, is defined by some scholars as a period of civic or "revolutionary nationalism". The State, on the levels of both policy and official discourse, stopped differentiating between its citizens according to their ethnic backgrounds and defined citizenship as the main marker of the Georgian identity. The government started protecting the rights of non-dominant religious communities and punishing extremists for hate crimes, however, it did not stop using the Church for political legitimacy. As a result, a number of crimes motivated by religious hatred significantly decreased. However, the level of education and acceptance of diversity in the society has not increased sufficiently. ${ }^{1}$ Despite multiple reforms, including in the sphere of education, systemic problems still exist. The State has adopted non-discriminatory legislation on general education, harmonised with international obligations and FoRB standards; however, in practice it has not demonstrated a commitment to implement the law sufficiently and to establish religious neutrality at public schools.

Since 2012, after the change of the government, the FoRB status and statereligion relations were modified again. The GOC interfered more actively with political and legislative matters and in certain cases, thus influencing the content of the legislation. The State increased material support for GOC by giving a considerable amount of property and land free of charge in addition to direct state funding. Simultaneously, the government's response to the crimes committed on the grounds of religious intolerance became weaker, thus encouraging similar violations of FoRB and increasing the statistics of

1 CRRC, Hate crime, hate speech and discrimination in Georgia: attitudes and awareness (Council of Europe, 2018), p. 17. 
uninvestigated hate-crimes. ${ }^{2}$ The state's relation towards religious minority communities has become the subject of criticism on numerous occasions. In 2014 the Government created a special entity focused on religious matters, the State Agency for Religious Issues. The work of the Agency has been criticised by religious and human rights organisations for being oriented towards the control of religious communities rather than protecting FoRB and equality among religious groups. ${ }^{3}$

\section{$2 \quad$ Legislative Framework of FoRB}

Freedom of religion or belief is enshrined in the Constitution of Georgia. Other laws also create conditions for the protection of this fundamental right. However, the GOC enjoys special privileges and status, which results in unequal and differential conditions for non-dominant religious organisations. The legislation contains several discriminatory provisions and shortcomings, while the general legislative framework is in compliance with international FoRB standards.

The Constitution of Georgia was adopted in 1995, after the country had gained political independence from the Soviet Union. Article 16 of the Constitution guarantees freedom of belief, religion, and conscience for all. It prohibits persecution of a person based on their religion or belief or compulsion to express an opinion about it. The constitutional provision contains legitimate aims for the restriction of FoRB. The limitation clause was amended in 2018 after a series of discussions and criticism voiced by civil society.

Freedom of religion and belief is further enshrined in Article 8 of the Constitution. It brings forward the idea of independence of the Church from the state, declares the GOC and the state to be independent agents and differentiates their respective spheres, which is the very essence of secularity. The constitution does not provide a more specific clause of separation of religion

2 According to the reports and data of Public Defender of Georgia and the Christian Organization of Jehovah's Witnesses, 12 crimes were registered in 2010-2012 and 122 crimes in 2013-2016.

3 Tolerance and Diversity Institute (TDI), TDI on the report and the strategy of religious policy prepared by the state agency for religious issues, 23 February 2015, <tdi.ge/en/news/16otdi-report-and-strategy-religious-policy-prepared-state-agency-religious-issues $>$, accessed 14 May 2019. See also No To Phobia Platform, 'NO TO PHOBIA', statement on the attempt of the state agency for religious issues to acquire personal information on clergymen from different religious confessions <notophobia.ge/eng/view-resources/statements/45>, accessed 14 May 2019. 
and state. Therefore, the abovementioned provision is the only and main guarantee for the separation of state and religion.

After the 2018 amendments, Article 8 of the Constitution considers freedom of belief and the special role of the Georgian Orthodox Church as proportional/equal values. ${ }^{4}$ 'Together with freedom of belief and religion, the State recognises the special role of the Apostolic Autocephalous Orthodox Church of Georgia in history .....5 This formulation may create grounds for the assumption that the State restricts FoRB through recognising the role of the Orthodox Church. After the constitutional amendment in 2001, a new provision was added granting a special role to the Goc. As a result, Article 8 further declares that the relations between the State and GOC are regulated by the Constitutional Agreement.

This Constitutional Agreement between GOC and the State was concluded on 14 October 2002. It grants considerable privileges to the Church, determines its legal status and declares it as a historically formed legal entity under public law. It is noteworthy that until 2005, other religious organisations were not even entitled to register as legal entities. Under the Constitutional Agreement, the State recognises the material and moral damages inflicted to the GOC during the Soviet times and assumes the responsibility for partial compensation of material damages. It acknowledges the ownership by the GOC of the Orthodox churches, monasteries (functioning and not-functioning), their ruins, as well as land plots on which they are located; exempts the GOC from certain taxes; regulates exceptions to military service; grants some privileges in the field of public education, recognises church marriage conducted by the GOC, among other privileges.

The text of the Constitutional Agreement is not discriminatory itself, as it is as such an agreement concluded between two parties and does not contain provisions prohibiting the same rights to other religious organisations. However, the State has not signed similar agreements with other religious organisations. Also, a number of benefits for the GOC envisaged by various laws are derived from the Constitutional Agreement. Therefore, the approach of the State towards religious organisations can be deemed as selective and discriminatory. Furthermore, both, the GOC and State often justify the privileges of the GOC with the Constitutional Agreement and the historical role of the Church.

4 The previous version (former Article 9) recognized separately: (i) full freedom of religion; and (ii) the special role of the Orthodox Church in the history and its independence from the State.

5 Constitution of Georgia (1995), Art. 8 (emphasis added). 
In this regard, the Constitutional Court of Georgia in 2018 made a very important statement and pointed out that 'recognition of the special role of the Church is related to its historical contribution and does not serve the purpose to create privileged legal conditions for the GOC at the present time. ${ }^{6}$ Hence, granting certain rights to the GOC does not imply the creation of obstacles for other religious organisations to enjoy the same rights. ${ }^{7}$

\subsection{Constitutional Amendments: Impermissible Limitations of FoRB on Grounds of State Security}

In 2017, the Parliament of Georgia initiated the draft amendments to the Constitution of Georgia. The amendments, among other issues, affected the provisions of freedom of religion or belief. The Parliament of Georgia added ambiguous criteria, such as 'state security, prevention of crime and implementation of justice' as legitimate aims for the restriction of FoRB. ${ }^{8}$

According to the previous edition of the Constitution, freedom of belief, conscience, and religion could be restricted only if it violated the rights of others. As a result, the provision on limitations in the draft amendments to the Constitution weakened the standards of protection of freedom of belief, religion, and conscience and imposed the threat of arbitrary interference with fundamental rights.

Regarding the new constitutional amendments, the Council of Europe's Venice Commission recommended to redraft the disputable Article 16(3) in the light of the second paragraph of Article 9 ECHR. ${ }^{9}$ The Venice Commission emphasised that the provided grounds did not represent legitimate aims for interfering with freedom of religion or belief and referred to the case-law of

6 LEPL Evangelical-BaptistChurch of Georgia,LEPL Word of Life Church of Georgia, LEPL Church of Christ, LEPL Pentecostal Church of Georgia, LEPL Trans-Caucasian Union of Seventh-Day Adventist Church, LEPL Caucasus Apostolic Administration of Latin Rite Catholics, Georgian Muslims Union, LEPL Holy Trinity Church v. Parliament of Georgia, 3 July 2018, Constitutional Court of Georgia, No. 1/2/671.

7 Ibid. See also LEPL Evangelical-Baptist Church of Georgia, LEPL Evangelical-Lutheran Church of Georgia, LEPL Highest Administration of all Muslims in Georgia, LEPL The Redeemed Christian Church of God in Georgia, LEPL Pentecostal Church of Georgia v. Parliament of Georgia, 3 July 2018, Constitutional Court of Georgia, No. 1/1/811.

8 Mariam Gavtadze, Georgia: Constitutional Changes to impose impermissible freedom restrictions?, <www.forum18.org/archive.php?article_id=2316>, accessed 10 July 2019.

9 Opinion of the Venice Commission on Draft constitution, 19 June 2017, European Commission for Democracy Through Law (Venice Commission), Opinion 876/2017, CDL-PI (2017)oo6, para. 39 . 
the European Court of Human Rights, pursuant to which the State cannot restrict freedom of religion on the grounds of national security. ${ }^{10}$

It is important to note that the mentioned approach is considered by the ECtHR as one of the foundations of a democratic society. In the case of Nolan and $K$. v. Russia, the Court provided:

Paragraph 2 of Article 9 of the Convention does not allow restrictions on the ground of national security. Far from being an accidental omission, the non-inclusion of that particular ground for limitations in Article 9 reflects the primordial importance of religious pluralism as one of the foundations of a 'democratic society' within the meaning of the Convention.11

With regard to the scope of permissible limitation clauses, the Human Rights Committee's General Comment no. 22 also emphasises that Article 18 (3) of the Covenant 'is to be strictly interpreted: restrictions are not allowed on grounds not specified there, even if they would be allowed as restrictions to other rights protected in the Covenant, such as national security'. ${ }^{12}$

A considerable number of religious organisations, human rights NGOs, and lawyers advocated against these amendments and drafted several statements addressing the Parliament, the President, the Venice Commission, and all relevant international organisations. ${ }^{13}$ Religious and human rights organisations complained that the criteria for imposing limitations on FoRB were not foreseeable and created a high risk for their misuse.

As a result, in October 2017, the President of Georgia vetoed the mentioned amendment and proposed a new formulation of the article. On 13 October of that year, the Parliament overturned the President's objections. However, the Chairman of the Parliament declared that they would start reconsidering the freedom of religion article immediately and respectively and new amendments had been initiated soon after. The problematic provisions (restriction of FoRB based on national security, prevention of crime and implementation of

\footnotetext{
$10 \quad$ Ibid.

11 Nolan and K. v. Russia, 12 February 2009, European Court of Human Rights, No. 2512/o4, para. 73 .

12 UN Human Rights Committee, General Comment no. 22-Article 18 (Freedom of Thought, Conscience or Religion) (CCPR/C/21/Rev.1/Add.4), para. 8 [General Comment No. 22].

13 Address of Civil Society Organizations and Lawyers on Limitation of Freedom of Religion in Draft Amendments to the Constitution of Georgia, 2 August 2017, Tolerance and Diversity Institute, $<$ tdi.ge/en/statement/address-civil-society-organizations-and-lawyers-limi tation-freedom-religion-draft>, accessed 14 May 2019.
} 
justice) were removed from the draft constitution. The final text was adopted by the Parliament on 23 March 2018 which states that freedom of religion and belief 'may be restricted only in accordance with law for ensuring public safety, or for protecting health or the rights of others, insofar as is necessary in a democratic society.' ${ }^{\prime 4}$

The final reading of the limitation clause was welcomed by religious and human rights organisations. However, contrary to international doctrine, it does not include "public morals". The limitation of the fundamental right based on morals is often challenging and leaves a fairly broad margin of appreciation for States to define the meaning and the "necessity" of the measures in order to protect public morals. Taking into consideration the high authority of the conservative dominant religious institution and fledgling democracy in the country, the protection of "morals" could be called upon to justify the restriction of several essential rights granted by the Convention and domestic law, without pinpointing its scope and boundaries.

\subsection{Conscientious Objection}

Conscientious objection to military service is based on the right to freedom of thought, conscience and religion, set out in the Universal Declaration of Human Rights (Article 18) and the International Covenant on Civil and Political Rights (Article 18). While the Covenant does not explicitly refer to a right to conscientious objection, in its General Comment No. 22 (1993), the Human Rights Committee stated that 'such a right could be derived from article 18, inasmuch as the obligation to use lethal force might seriously conflict with the freedom of conscience and the right to manifest one's religion or belief.'15

Since the adoption of this General Comment, the Human Rights Committee has repeatedly referred to the prohibition of discrimination 'among conscientious objectors on the basis of the nature of their particular beliefs. ${ }^{16}$ The Committee points out that State parties should widen the grounds for conscientious objection in law so that they apply, without discrimination, to all religious beliefs and other convictions, and that any alternative service for conscientious objectors be performed in a non-discriminatory manner. ${ }^{17}$

\footnotetext{
14 Constitution of Georgia, Art. 16.

15 General Comment No. 22, supra note 12, para. 11.

16 UN Office of the High Commissioner on Human Rights (OHCHR), Conscientious Objection to Military Service, No. E/12/XIV/3, p. 22.

17 UN Human Rights Committee, Concluding observations of the Human Rights Committee: Ukraine, CCPR/CO/73/UkR, para. 20; see also UN Human Rights Committee, Concluding observations of the Human Rights Committee: The Kyrgyz Republic, CCPR/CO/69/KGZ, para. 18.
} 
Today in Georgia, believers who have a conscientious objection to military service can choose an alternative to the military service according to the Law of Georgia on Military Duty and Military Service and the Law on Military Reserve Service adopted in 2018. Until 2011, the Law on Military Reserve Service ${ }^{18}$ obliged every citizen of Georgia to serve and did not allow an exception for those people who had a conscientious objection, for instance, Jehovah's Witnesses - who were not even allowed to ask for alternative service. ${ }^{19}$

In 2011, the Constitutional Court of Georgia in the case of Public Defender of Georgia v. the Parliament of Georgia declared Article 2, clause 2 of the Law of Georgia on Military Reserve Service unconstitutional, in respect of the Constitution's Article 14 (equality before the law) and article 19 (freedom of religion and belief). ${ }^{20}$ This law declared it a duty of each and every citizen of Georgia to serve in military reserve. Hence, the provision at hand implied forcing people with a conscientious objection to act against their beliefs. They had the following alternatives - either to fulfil military reserve service against their beliefs, or to act in accordance with their own beliefs, but for this, they would bear the responsibility imposed by the law. Failure to serve in military reserve even on the ground of objection was considered a violation of the Code of Administrative Offences and could be punished with the imposition of a fine.

In its judgment on the matter, the Constitutional Court set out that the provision implied forcing people with a conscientious objection to act against their beliefs. It provided:

The source for "conscientious objection" is the personal belief that forbids taking away someone's life. Accordingly, conscientious objectors generally reject armed service during war and peace as the war necessarily includes using the force and taking away human life. As long as military service serves the defense capabilities of a state, it also means preparing for the warfare. Therefore, conscientious objection means rejection of military service not only during the war but also in peacetime. ${ }^{21}$

On 23 March 2018, the Parliament adopted a new law on reserve service. The law provides that a person who has a conscientious objection shall perform an alternative, non-military service. Citizen performing an alternative to the

\footnotetext{
18 Law of Georgia on Military Reserve Service, No. 4196, 1 June 2018 (annulled).

19 Law of Georgia on Military Reserve Service, 27 December 2006, Article 2.2.

$20 \quad$ Public Defender of Georgia v. The Parliament of Georgia, 22 December 2011, Constitutional Court of Georgia, No. 1/1/477, available at <www.constcourt.ge/uploads/other/2/2485 .pdf>.

21 Ibid., para 16.
} 
military service shall enjoy all rights guaranteed by the Constitution. Those who accomplish alternative labour service are listed in a reserve list and may be drafted for non-military purposes.

\subsection{Inequality in Legislation}

As pointed out above, violations of FoRB and differential treatment of religious organisations stem from either State policy or existing shortcomings in legislation. In respect to the latter, it is noteworthy to refer to important provisions imposing impermissible limitations for religious communities to freely exercise FoRB in an equal, non-discriminatory manner.

In 2018, the Constitutional Court of Georgia granted two complaints of religious organisations ${ }^{22}$ about tax inequality and discriminatory provisions within the Law on State Property and declared some disputed norms unconstitutional, in the light of Article 14 (equality before the law) of the Constitution of Georgia. ${ }^{23}$ Religious organisations had been demanding the elimination of inequality in Georgian legislation and changes to overall discriminatory treatment for many years. The problem has been systematically reflected in the reports of the Public Defender (Ombudsperson) of Georgia, as well as reports by international and local organisations.

According to the Tax Code of Georgia, only the GOC is exempted from certain taxes for religious purposes, including the realisation of religious items, the supply of liturgical items, restoration, construction and painting of churches and temples and land (property) taxes. Consequently, the norms mentioned above put all other religious organisations in an unequal position and violate those religious groups' constitutional rights. In 2015, eight religious organisations applied to the Constitutional Court of Georgia with a claim requesting to find those norms unconstitutional. ${ }^{24}$

Pursuant to the Law of Georgia on State Property, religious organisations registered as Legal Entities of Public Law (LEPL) - except the GOC-are deprived of the possibility to purchase state property by direct sale. Also, the regulation allows the transfer of state property free of charge only to the Georgian Orthodox Church. Hence, these provisions create obstacles for all other religious organisations, put them in unequal conditions, and violate

\footnotetext{
22 LEPL Evangelical-Baptist Church of Georgia, supra note 7.

23 Tolerance and Diversity Institute, Constitutional Court granted two complaints of religious organizations, <tdi.ge/en/news/6o2-constitutional-court-granted-two-complaints -religious-organizations $>$, accessed 14 May 2019.

24 Tolerance and Diversity Institute, Eight Religious Organizations Applied to Constitutional Court of Georgia, <tdi.ge/en/news/256-8-religious-organizations-applied-constitutional -court-georgia>, accessed 10 July 2019 .
} 
their constitutional rights. In 2016, a further five religious organisations submitted a claim to the Constitutional court. ${ }^{25}$

The Court partially admitted the claims. With two decisions of 3 July 2018, the Court declared unconstitutional the provisions according to which building, restoration, and painting of temples and churches ordered by the GOC are exempted from tax. ${ }^{26}$ In the second claim, the provision of the Georgian Law on State Property that provided a privilege exclusively for the GOC to receive state property free of charge was also declared unconstitutional. ${ }^{27}$

\subsection{Criminal Law and Investigation of Hate Crimes}

Restriction of FoRB is punishable under Georgian legislation. The Criminal Code prohibits unlawful obstruction to performing worship and religious rites, persecution of the person due to their faith or religion, and interference with the establishment of a religious organisation. Violations are punishable by fines, imprisonment, or both. Furthermore, the commission of crimes on the grounds of religious intolerance is declared as an aggravating circumstance for all crimes which do not contain the motive of intolerance as the crime element.

However, the law is not always enforced in practice. For instance, during the last few years, several cases of systematic violation of Muslims' rights occurred in different regions of Georgia (e.g. in Nigvziani (2012), Tsintskaro (2012), ${ }^{28}$ Samtsatskaro (2013), Chella (2013), Kobuleti (2014), Mokhe (2014), Adigeni (2016)). ${ }^{29}$ Muslims were restricted from holding religious rituals and keeping their houses of worship, some of them were banished from the village and verbally abused by the Orthodox majority. No measures were taken by the State for the deterrence of such facts. The State dismantled the minaret of the mosque in the village Chella and generally not only tolerated but even fostered the violence. ${ }^{30}$ Some cases are still unsolved; perpetrators, allegedly involving police officers, have not been punished.

Jehovah's Witnesses remain the most vulnerable religious community in Georgia. Crimes committed against the members of this religious organisation

25 Tolerance and Diversity Institute, Religious Minorities Apply to Constitutional Court, $<$ tdi.ge/en/news/352-religious-minorities-georgia-apply-constitutional-court>, accessed 10 July 2019 .

26 LEPL Evangelical-Baptist Church of Georgia, supra note 6.

27 LEPL Evangelical-Baptist Church of Georgia et al. v. Parliament of Georgia, No. 1/1/811.

28 Felix Corley, Will Police Protect Muslim Prayers from Mobs?, <www.forumı8.org/archive .php?article_id=1854>, accessed 10 July 2019.

29 Tamta Mikeladze et al., Freedom of Religion-Critique of Discriminatory and Non-Secular State Policy (Tbilisi: Human Rights and Monitoring Center, 2016), pp. 87-95.

30 Tolerance and Diversity Institute, Joint Statement of CSOs Concerning Violation of Muslims' Rights in Village Mokhe, <bit.ly/2LjCtdG>, accessed 10 July 2019. 
include, among others, physical and verbal assault, damage of religious literature or property, and vandalism against the places of worship. ${ }^{31}$ The European Court of Human Rights adopted three judgments against the State all concerning violations of the rights of Jehovah's Witnesses. The cases dealt with attacks and violence committed by the Orthodox clergy and their supporters against the Jehovah's Witnesses in 1999-2001. ${ }^{32}$ In all cases, the European Court of Human Rights found a violation of Article 9 of the Convention separately and in conjunction with Article 14, as the State could not ensure a tolerant environment, where the applicants would enjoy their freedom of religion or belief. The Court also found that the authorities failed to take measures to deal with the well-documented acts of violence, and furthermore established a lack of adequate and impartial investigation into these matters.

\section{Discriminatory State Policy and Practice while Limiting FoRB}

Apart from some provisions, the general legal framework is compatible with international FoRB standards; however, problematic restrictions imposed on FoRB are derived from State policy and practice. The cases below illustrate the structural problem of using impermissible limitations by the State when the law does not allow for such restrictions.

\subsection{Building New Houses of Worship and Property Rights}

The State often restricts religious minorities by refusing to issue construction permits for new houses of worship. This means taking away the right for a number of believers to assemble, worship, hold rituals and manifest their freedom of religion and belief. ${ }^{33}$ Such practice goes beyond the scope of permissible limitations and constitutes an arbitrary interference by the state with human rights and fundamental freedoms.

31 The dynamic of offences and crimes committed on the grounds of religious intolerance against Jehovah's Witnesses is documented by the Public Defender of Georgia: 12 crimes in 2010-2012, 17 in 2013, 45 in 2014, 37 in 2015, 23 in 2016, 15 in 2017 and 19 in 2018.

32 See 97 members of the Gldani Congregation of Jehovah's Witnesses and 4 Others v. Georgia, 3 May 2007, European Court of Human Rights, No. 71156/o1; Begheluri et al. v. Georgia, 7 October 2014, European Court of Human Rights, No. 2849o/o2; and Tsartsidze et al. v. Georgia, 17 January 2017, European Court of Human Rights, No. 18766/04.

33 Mariam Gavtadze and Eka Chitanava, GEORGIA: State obstructs building new nonGeorgian Orthodox places of worship, <www.forum18.org/archive.php?article_id=2118>, accessed 14 May 2019. 
Georgian legislation provides for a uniform standard of construction of any type of building, except specialised buildings (e.g. petrol stations). These general regulations for constructions apply to the building of houses of worship. Self-government bodies are legally entitled to issue building permits. However, despite the legislation establishing equal conditions for all, representatives of non-Orthodox Christian religious organisations often face artificial obstacles as a result of the discriminatory approach adopted by the State. Permits are often either not issued or arbitrarily cancelled. Usually, local councils take into consideration the opinion of the GOC clergy and parishioners who disagree with constructions. The official grounds for the denial or suspension of the permit is not related to the restriction of FoRB; instead, the State finds excuses to express its loyalty towards the Orthodox clergy and parishioners rather than respecting minority rights. ${ }^{34}$

As an illustration of the problem, several cases could be given. In 2014, in one of the cities in Western Georgia, Terjola, Jehovah's Witnesses came across such impediments. The beginning of construction of a house of worship in February 2014 was followed by a protest by representatives of the Orthodox Church and the local population. An Orthodox priest organised rallies against Jehovah's Witnesses, where local residents, public school teachers and even students participated. ${ }^{35}$ In June 2014, the building permit was suspended when the neighbour living in a nearby house, submitted an administrative complaint to the city council. He used the pretext that the building work damaged his own property. On the same day, the municipality council suspended the construction permit. Although Jehovah's Witnesses presented results of an engineering-geological examination which proved that construction did not have a negative impact on the environment and it posed no threat to nearby roads or any other property, the permit was not reissued. The State-run National Forensic Bureau, which is responsible for examining such claims, also refuted in its official written opinion the neighbour's complaint. Eventually, religious community members appealed the decision in the court and also requested reimbursement of material and moral damages. The court partially upheld the claim and ordered the municipality to renew the construction permit. The decision was further appealed in the Appellate Court, which charged the municipality to pay for the compensation of material damages. ${ }^{36}$ In 2015,

34 Ibid.

35 Public Defender of Georgia, Annual Report on the Situation of Human Rights and Freedoms in Georgia, 2014, p. 273 <ombudsman.ge/res/doc/2019o62409381078741.pdf>.

36 Public Defender of Georgia, Annual Report on the Situation of Human Rights and Freedoms in Georgia, 2015, p. 401. 
Jehovah's Witnesses brought the case to the Supreme Court, claiming discrimination on religious grounds and moral damages. However, the Supreme Court left the decision of the Appellate Court intact. ${ }^{37}$ It should be noted that during the litigation process Jehovah's Witnesses were offered by the local council "an alternative plot" to build their house of worship, "with a guarantee of peaceful coexistence" and avoiding religious confrontation. After two years of struggle, Jehovah's Witnesses resumed building their house of worship; however, the impermissible restriction on religious grounds by the State was not identified or acknowledged.

There have been cases when the construction process was halted due to non-legally binding opinions of government bodies. As an example, in 2015 an Evangelical Christian organisation applied to Tbilisi City Hall for a building permit. The City Hall established a specific condition for construction - they demanded a recommendation from the State Agency for Religious Issues. ${ }^{38}$ No provision refers to the necessity of submission of such document, hence recommendations of the Agency are not legally binding and the suspension of administrative proceedings - or refusal to review an application on this basis - should not be permitted. The religious organisation filed a lawsuit in the Tbilisi City Court. The court satisfied the claim and concluded that the administrative body was not authorised to request from the applicant any other additional document or information (including the recommendation of the Agency), except for the documents or information foreseen by the law. ${ }^{39}$ To summarise, in the given case the government used an administrative body as an instrument to limit one's manifestation of freedom of religion and created artificial barriers.

Yet another case demonstrates that administrative bodies go beyond the scope of permissible limitations and do not allow religious minority organisations to build new houses of worship. In the case of a Catholic Church, the religious organisation applied to the municipality of Rustavi in 2013. At the initial stage, the city hall approved the building conditions, which is the first phase defined by the legislation for issuing a building permit. However, on the next stage of the procedure, the council did not respond to the application. The council did not even inform the religious organisation about the final decision. After the Catholic Church applied to the City Court twice in 2014

37 Ibid.

$38 \quad$ Ibid.

39 Tolerance and Diversity Institute, Tbilisi City Court Upheld TDI's Complaint of the Case of Construction House of Worship, <tdi.ge/en/news/401-tbilisi-city-court-upheld-tdis-com plaint-case-construction-house-worship >, accessed 15 July 2019. 
and 2015 with the request to issue a construction permit certificate, the local government still was not responding. ${ }^{40}$ Catholics demanded recognition and elimination of results of discriminatory treatment. After reviewing the claim in 2015, the City Court separated the claims about discrimination from the case of administrative dispute, after which these Catholics ceased their request for recognition of discriminatory treatment and demanded solely the issuance of a construction permit. ${ }^{41}$ The given case demonstrates that the State used all available means to prevent issuance of construction permit. In addition, as the Court noted, according to the report of an interview between a representative of the Public Defender of Georgia and Governor of the region, the Rustavi City Hall held a meeting with local Orthodox Christians and the clergy. ${ }^{42}$ Despite the court's decision, the authorities still urged the construction of the church on an alternative plot. Eventually, Catholics built the church in a different location in 2018.

Building a house of worship is especially problematic for the Muslim community in Georgia. ${ }^{43}$ According to the 2014 national census, Muslims comprise more than 10 percent of the population. Georgian Muslims densely reside in the Achara region, the south-western part of Georgia, along the border with Turkey. Because of religious nationalist discourse and discriminatory state policy, Georgian Muslims are often restricted to express their religious identity in the public space.

The only mosque in Batumi cannot accommodate the high number of worshippers on religious festivals and Friday prayers. According to local religious activists, around 1,00o people pray outside the mosque building. In 2016, the Muslim community collected signatures of more than 12,00o citizens, asking for the allocation of a land plot for construction. Signatures were submitted to central and local authorities. However, they remained unanswered. Consequently, in 2017 Muslims applied to the Batumi City Hall to request a permit to build a mosque on the plot, purchased with their own resources. Batumi City Hall denied the construction permit through an unsubstantiated decision. In 2017, these Muslims appealed the decision in Batumi City Court. The case is still pending.

40 Gavtadze and Chitanava, supra note 33 .

$41 \quad$ Ibid.

42 Ibid.

43 Mariam Gavtadze and Eka Chitanava, GEORGIA: Government and Orthodox block Muslims regaining mosque, <www.forum18.org/archive.php?article_id=226o >, accessed 14 May 2019. 
As previously shown, local authorities use different approaches and instruments either not to issue or to suspend building permits for minority religious communities, despite the absence of impermissible limitations on FoRB in the legislation. Furthermore, the issue of a mosque construction in Batumi differs from other cases mentioned above. Impediments for building a new mosque stems from the policy and practice of not only local but also the central government. Because of the geographical closeness of Achara to Turkey and historical issues, Georgian nationalist populist groups and politicians often employ Turkophobic narratives and portray local Muslims as Turkish diaspora or agents of political and economic influence. Hence, construction of mosques is not considered by the State in the context of realisation of fundamental human rights of Georgian citizens to assemble, conduct religious rituals, and express their religious identity.

Apart from these impediments to build new houses of worship, some nondominant religious communities struggle to regain their seized temples. Since the dissolution of the Soviet Union and the restoration of the independence of Georgia, several religious organisations have still not been able to retrieve their historical property. The issue of property restitution in Georgia is crucial for the Armenian Apostolic, Catholic and Evangelical-Lutheran Churches, as well as Muslim and Jewish communities. Many such properties, most of which are cultural heritage monuments, have fallen into disrepair and some have even been destroyed or demolished. The majority of this property is under the State's ownership; however, a considerable number of historical temples previously owned by the mentioned religious communities had been transferred to the GOC by the State.

\subsection{Limitations on FoRB and Discriminatory Treatment in Public Schools}

Despite the fact that Georgia is a multi-confessional and multi-ethnic country, diversity and non-discrimination principles are not observed or respected at public schools. The Law on General Education of Georgia adopted in 2005 defines religious neutrality and non-discrimination as one of the key principles of public schools and aims to create an environment based on equality for all students. On the one hand, school settings aim to be religion-neutral, and at the same time, the law allows the accommodation of students' religious beliefs.

In practice, the "neutrality" and equality principles prescribed by the law are often violated. Religious indoctrination, proselytism (the attempt to convert students to a certain religion or belief), and the display of religious symbols for non-academic purposes (i.e. lighting candles, putting out icons for prayer) to the advantage of Georgian Orthodox Church adherents, frequently occur 
and remain a systemic problem. Representatives of non-Orthodox Christian religious communities refer to multiple facts of differentiation based on religious grounds. ${ }^{44}$ The Public Defender of Georgia regularly points to systemic problems within the education system in its annual reports.

Since the State does not address such violations, minority representatives sometimes are restricted from manifesting freedom of religion and belief in school settings. The below case demonstrates that sometimes the State imposes limitations on expression of religious conviction (forum externum) even though these restrictions are neither legally prescribed nor necessary to pursue a legitimate aim - the protection of public safety, order, health, or morals or the fundamental rights and freedoms of others.

Religious attire can form a significant element of religious identity and is an important aspect of religious observance and practice. The question of how to respond to religious attire in public spaces has traditionally been considered from a human rights perspective. Although a number of countries have different approaches to ensure religious accommodation and balance this freedom with other rights. At the same time, it is significant that any prohibition on religious attire should comply with the test of proportionality after a detailed factual examination which reflects the context of the prohibition and the rights of others, such as students and teachers.

In 2017, in one of the villages of Georgia, Mokhe, the school administration imposed an extra-legal ban on wearing a headscarf for a Muslim student. The law on General Education, as well as Mokhe's school administrative regulations do not mention any ban on the hijab or any other kind of religious attributes in public schools. ${ }^{45}$ The ban also comes in conflict with the Constitution of Georgia. ${ }^{46}$

The Ministry of Education audit department studied the case and concluded that neither restriction of FoRB nor discrimination on religious grounds could be identified. While analysing the case, it is important to take into consideration the context and political events occurring in the same village. The majority of Mokhe population is composed of Muslims. They have long sought the return of their half-ruined mosque, which had been confiscated during the Soviet times and later registered by the local municipality as its property. In 2014, the State tried to dismantle the former mosque, which

44 Tolerance and Diversity Institute, Assessment of the Needs of Religious Organizations in Georgia, <tdi.ge/sites/default/files/assessment_of_the_needs_of_religious_organizations _in_georgia_tdi.pdf $>$.

45 Gavtadze and Chitanava, supra note 43.

46 Constitution of Georgia, Art. 11 and Art. 16. 
turned into verbal abuse and physical violence against Muslims, including allegedly by police officers. ${ }^{47}$ No perpetrators were brought to justice.

After these incidents, the Georgian Orthodox Church also claimed its ownership of the building, referring to the argument that the former mosque had been built by using stones from the churches previously located in the same area. However, no substantial historical evidence was provided by the Church. The head-teacher of Mokhe public school proved to be a member of the Orthodox Christian parish, who organised a series of prayer vigil in front of the former mosque and publicly stated that the building belonged to the Orthodox congregation; ${ }^{48}$ this being the same head-teacher banning the Muslim school student from wearing a headscarf during school hours.

In this particular case, the Ministry did not find any violations of the law and based restriction of one's freedom of religion or belief on several arguments. Firstly, according to the Ministry's conclusion, wearing a headscarf and all types of head covering was prohibited not only for a particular student, but for all students. ${ }^{49}$ This argument lacks cogency since the internal regulations of the school do not mention any prohibition about religious head-covering or religious clothes. It is pointed out in the regulations that students shall not wear hats and dyed hair; yet if this was indeed the applicable norm the administration ignored the religious significance of the headscarf.

Secondly, the display of religious symbols would be prohibited according to the Law on General Education..$^{50}$ In fact, the legislation bans the display of religious symbols (i.e. candles and icons) for non-academic purposes (i.e. while holding services, prayer, or other religious rituals) by the administration of the school and this limitation does not extend to religious attire worn by students. In this case, the neutrality principle provided by law is confused with the obligation of the school administration to accommodate religious convictions of all students. ${ }^{51}$ When assessing the proportionality of any restrictions on religious expression, the interest of equality should be taken into account. In the given case, Christian students are not restricted to wear crosses or other religious attributes to express their religious identity. It is not explained why such restriction may apply particularly to Muslim students wearing headscarves.

\footnotetext{
47 Gavtadze and Chitanava, supra note 43.

48 Ibid.

49 Tolerance and Diversity Institute, TDI Addresses the Ministry to Study the Alleged Fact of Discrimination at Mokhe Public School <tdi.ge/en/news/399-tdi-addresses-ministry-study -alleged-fact-discrimination-mokhe-public-school>, accessed 15 July 2019.

$5^{\circ}$ Law of Georgia on General Education (1330-LHG, 20, 04/05/2005), Art. 18, <matsne.gov .ge/en/document/download/29248/56/en/pdf>. 
Hence the approach adopted violates the right of manifestation of FoRB and should have been considered as impermissible pursuant Georgian legislation.

Thirdly, the argument was made that the 'prohibition is justified by the aim of avoiding religious fuel or conflict against the backdrop of the events occurring in reference to the mosque. Hence, the factors that could escalate the confrontation should be subjected to certain lawful prohibitions. ${ }^{52}$ According to the Constitution of Georgia, permissible limitations on freedom of religion include the necessity of such restrictions in a democratic society, public safety, health and protection of the rights of others. In the context of religious attire, these limitations may, for example, be used to justify the removal of face veils in order to ensure proper identification at national borders or to justify restrictions on some garments in order to limit infection control in hospitals. In the given case, the Ministry did not provide any argumentation based on empirical evidence as to how the wearing a headscarf by a school student could foster confrontation between the Muslim and Christian population of the village or how this could pose any threat to public safety.

In September 2017, the Public Defender of Georgia addressed the Ministry with the recommendation to take effective measures to allow public school students to express their religious identity freely and avoid discrimination on religious grounds. ${ }^{53}$ The Public Defender pointed out that a headscarf worn by the Muslim student expresses her religious identity and belonging to the Muslim community, hence reducing this symbol of identity to a mere matter of clothing regulation undermines the importance of the issue in the light of human rights protection.

\section{4 Conclusion}

As an overview of state practice and case-law in Georgia shows, the state fails to officially base restrictions of religious activities on recognized legitimate aims to limit FoRB. The case-law is rather scarce in this regard. The common courts usually consider the cases in the light of various administrative procedures (e.g. violation of construction rules). Despite the fact that in many cases state officials declare that they apply limitations to safeguard "harmony and peace among religious groups", or to "avoid extremism and external threats",

$5^{2} \quad$ TDI, supra note 49 .

53 Open Society Georgia Foundation, The Right to Non-Discrimination in Practice for Various Groups in Georgia, 2017, <www.osgf.ge/files/2018/Publications/Discrimination_Eng.pdf> p. 5 . 
officially all these restrictions are recorded differently—without making reference to FoRB and the legitimate aims for its limitation.

Only the Constitutional Court of Georgia has considered the cases related to equality and freedom of religion or belief and has given relevant interpretations and definitions. The ECtHR has already ruled on important cases of Jehovah's Witnesses and found a violation of Article 9, as the state did not ensure the protection of the rights of religious minorities. The instances of violation of FoRB that took place during the last years (i.e. arbitrary restrictions to build houses of worship, lack of investigation of hate crimes) are potential cases for ECtHR after the domestic remedies are exhausted.

During the last years, the state's desire to interfere with freedom of religion or belief with the aim to safeguard "state security" is particularly alarming. Religious minorities and human rights organisations have been playing an outstanding role to secure FoRB and to prevent the state from adopting legislation that would endanger the exercise of freedom of religion.

Considering the use of limitations of FoRB in Georgia, the conclusion must be that the absence of relevant case law of the common courts is the most striking and State policy and practice remains rather problematic because of omission. The systemic problems revealed during the analysis are as follows: the state imposes limitations by means of discriminatory provisions in the law; local and state authorities create artificial obstacles; attempts of securitizing FoRB are discernible as are inadequate responses to hate crimes committed as a result of religious intolerance. One of the overarching problems is the state's preferential treatment of the dominant religious group-the Goc. Consequently, the rights of non-Orthodox religious community members are often violated and their freedom of religion is limited due to the state's neglectful or discriminatory policies. 